\title{
PROBLEMS OF MODERNIZATION OF PROFESSIONAL PREPARATION OF THE STUDENTS OF PEDAGOGICAL HIGHER EDUCATION INSTITUTIONS
}

\begin{abstract}
The article touches upon the problems of modernizing the professional preparation of the students of pedagogical Higher Education Institutions (HEls). It proves that the deepening of market relations and the contemporary level of the development of public life put great demands on the HEls in terms of preparing highly qualified specialists. Due to the socio-economic transformations, it is required that the entire education system of pedagogical HEls should be reformed and a new graduate model should be elaborated. Among the significant problems, the authors single out the modernization of the system of the specialist preparation, the elaboration of new integrated educational strategies, models and technologies for the development of higher education systems, mutual understanding and collaboration among various education systems. Therefore the issues of the future specialists' professional competency, reflective teaching/learning, the development of meta-competences, competitiveness and media literacy come to the fore. The solution to these problems implies a change in the requirements of the HEI graduate model, approaches and expected outcomes. The problem of developing a new methodology for the preparation of specialists in pedagogy at HEls and improving the quality of the professional preparation should be considered in terms of functional, systematic, cultural, competence and anthropological approaches. The article provides justification for the claim that the process of the future pedagogues' professional preparation should be regarded as the integrity of interrelated structural components, including the aim, content, management, operation, outcome. The effectiveness of the professional preparation at contemporary pedagogical HEls is conditioned by certain managerial functions, principles, methods, implementation of innovations into the management of the higher education policy and the modernization of the content of the graduate model. The article presents social pedagogical conditions for the effective preparation of the HEI students and highlights a number of factors that contribute to the effectiveness of this process.
\end{abstract}

Keywords: professional preparation, modernization of education, professional competency, pedagogical education, metacompetences, educational needs, professional upbringing, state security. 


\section{Introduction}

The contemporary information society, in which we live, requires changes in different spheres of society. The sphere of higher education is no exception in this regard. The solutions to the existing problems here are impossible without the implementation of new educational paradigms and educational technologies.

It is out of the question that HEls play a unique role in this process. They should be prepared to solve the wide range of problems that may arise and to meet the needs of the beneficiaries of education through expanding the opportunities provided.

In addition to providing the students with high-level professional knowledge, HEls should also be a favourable educational-cultural environment in which cultural, human and ethical values are transferred, value orientations are formed, and a maximum agreeable socio-professional environment is created to ensure the implementation of student-centred education and the increase of the effectiveness of professional preparation.

The gradual deepening of market relations in public life and the current level of the development of information technologies place great demands on the HEls in terms of preparing highly qualified specialists.

The modernization of education in the contemporary phase of the sustainable development of society implies a change of the educational paradigm [1, p. 13].

The famous American physicist, historian and philosopher Thomas Kuhn believes that in the contemporary phase of the development of the society some paradigmatic changes of education are outlined, a humanitarian and anthropological turn is taking place in the philosophy of education, which requires a new methodology for the study of the personality and education [2, p. 2].

Due to the socio-economic transformations and the demands of the contemporary educational paradigm, reforms of the entire education system of HEls and elaboration of a new graduate model are required.

As stated by V. Popkov and A. Korzhuyev: "Higher professional education is the most important social state institution that performs the function of preparing the young generation to solve professional tasks in the future in a certain field of activity requiring quite a high level of various abilities and skills, including the skill to continuously improve them" [3, p. 10].

Meeting the educational needs of the transforming society is impossible without the technological assurance of the preparation of highly qualified specialists. That is to say, the modernization of the system of specialist preparation is a priority issue, and this trend is common in all the countries of the world. This, of course, presupposes elaboration of a new system of 
integrated strategies, models and technologies for the development of the higher education system, as well as mutual understanding and collaboration among various education systems. Naturally, the following issues are brought to the fore: the improvement of the future specialists' professional competency, reflectivity, teaching/learning process, metacompetences, competitiveness and media literacy.

V. Simonenko and M. Retivykh characterize professional competency as an integral character of the specialist's activity and personal qualities, which reflects the level of knowledge, abilities, skills, as well as experience [4, p. 66].

However, in the present phase of the preparation of a graduate in pedagogy, it is necessary to take into account the issues of the development of not only competences but also metacompetences.

According to M. Bogo, the specialist's meta-competence "represents the person's conceptual, interpersonal, professional characteristics. It includes the students' cognitive, critical and self-control reflective abilities" [5, p. 6].

"Metacompetences are considered a prerequisite for the development of such abilities as judgment, insight, and intelligence, upon which competencies are based, and without which they cannot perform any function" [6, pp. 43-53].

Considering the urgency of the solution to the mentioned problems, it has become necessary to develop a concept aimed at modernizing the higher pedagogical education, the content of professional activities, the implementation of contemporary technologies, as well as the development of professional competences and metacompetences. Solving these problems also ensues a change in the nature of the requirements, approaches and expected outcomes of the HEI graduate model. The problem of developing a new methodology for the preparation of specialists in pedagogy at HEls and improving the quality of the professional preparation should be considered in terms of functional, axiological, cultural, competence and anthropological approaches.

Studies show that in the process of the students' professional preparation nowadays, one can notice incompletely formed practical skills and a decline in motivation. This phenomenon is associated with the pedagogues' low salary, the inadequate perception of the role of the school and the wrong choice of profession.

In our opinion, the main reasons for the above-mentioned are the following:

- the incorrect perception and evaluation of the professional value system;

- the absence of the educational-cultural environment necessary for the effectiveness of the professional preparation at pedagogical HEls, and the presence of uncoordinated and unjustified reforms resulting in a decline in quality; 
- the inadequacy of the new strategies for upgrading the professional qualification of the HEI teaching staff with the problems of higher education modernization.

We think that the elimination of these reasons will result in a new quality of the development of the pedagogical profession. As E. Balakireva states: "The pedagogue's profession is a fully evolving phenomenon, both historically and socioeconomically" [7].

Considering the historical perspective of the pedagogical profession, we agree with the viewpoint that initially the pedagogue was entrusted with two crucial functions: the function of adaptation and that of personality formation.

Our long work experience shows that the pedagogue's profession should primarily be viewed from the perspective of the national and/or state security. However, its socio-economic significance is indisputable if we consider the fact that the pedagogue's profession is in high demand in the educational market, and it is a primary factor for the country's economic development.

With regard to modernizing the content of professional preparation at contemporary pedagogical HEls, a number of professional problems that need urgent solution can be identified. Among them are:

1. the systematic improvement of the compulsory trainings and qualification of the HEI teaching staff;

2. the need to change the system of the standards and assessment of the pedagogue's professional education and its alignment with the criteria of the level of the developed practical skills and professional qualification;

3. limiting the number of subjects that provide the students with additional information but do not develop any specific professional skills and competences;

4. increasing the number of pedagogical subjects, ensuring a socio-professional environment that will contribute to the development of subject-subject relations and the students' professional competency;

5. providing reflective teaching that will lead to the teacher's rapid development in professional activity;

6. intensive implementation of contemporary teaching methods, technologies and means in the process of teaching at HEls;

7. making the students' professional upbringing and professional socialization a priority issue for the university.

We agree with the idea expressed by A. Ghukasyan, L. Asatryan and A. Karapetyan that: "In the current phase of the development and reforms of the education system the traditional orientation of professional education to the preparation of a teacher of a particular subject cannot 
guarantee a high level of preparation. Therefore there is a need to revise the professional teaching goals and the quality standards of pedagogues' preparation" [8, p. 110].

The process of the professional preparation of future pedagogues should be regarded as the integrity of the following interrelated structural components: aim, content, forecast, management, operation, reflection, outcome. In developed countries, reflective teaching is considered an essential factor for the assurance of the teaching quality. The teaching of reflection can be carried out through clearly defined cycles and procedures. In each cycle, the teacher constantly monitors, evaluates and improves his/her activities [9].

The effectiveness of the professional preparation at contemporary pedagogical HEls is conditioned by certain managerial functions, principles, methods, implementation of innovations into the management of the higher education policy and the modernization of the content of the graduate model.

HEl students are equal subjects of education, upbringing, self-development, self-realization and socio-cultural self-determination. The core of professional education is the formation of professional knowledge and competences. And the aim of professional upbringing is the development of the students' civic and spiritual-moral qualities, their value system, which presupposes a socio-professional environment with maximum creative conditions to enhance the effectiveness of the students' professional preparation.

In pedagogical, scientific literature, there are various approaches to the problem of improving the content of professional education. Student-centred education is based on the humanistic paradigm that assumes a humanitarian approach to the learner's personality, differentiated instruction, taking into account the students' educational goals and age characteristics and considering them as the highest value ever [10, p. 281].

The learner-centred humanistic paradigm also implies the creation of an agreeable educational environment where the students' subjectivity, creative potential and collaboration skills are demonstrated and developed. Due to the importance of the role of the educational environment, it should be noted that the creation of the student-centred teaching and upbringing environment at HEls is also the basis for the improvement of the content of professional education.

Considering the social pedagogical conditions of the effectiveness of HEI students' professional preparation, we also highlight a number of contributing factors:

- psychological,

- social,

- material and technical,

- information and technological. 
In this context, the following social-pedagogical conditions for the effectiveness of students' professional preparation should be highlighted:

- forecasting the trends, risks and outcomes of the development of students' professional education;

- reputation and competitiveness of $\mathrm{HEl}$;

- educational-cultural environment of HEl;

- development of a productive student-teacher interaction environment, an important component of which, in our opinion, is the lecturers' professional competency and the facilitation process carried out by them;

- the reflectivity of the subjects (lecturers and students) of the educational process;

- pedagogical support in the process of adapting students to the educational-cultural environment and educational process of $\mathrm{HEl}$;

- creating an adequate environment for achieving academic freedom and good academic conduct on the part of the lecturers and the students.

The need to solve the problems in the field of professional education requires the students to prove themselves as self-governed subjects, achieve their learning goals, develop their communicative, organizational skills, value their own role and attach high importance to it.

\section{Conclusion}

As a result of the content analysis and the study of the professional preparation process of the students at pedagogical HEls, the following social pedagogical conditions have been highlighted:

- forecasting the trends, the risks and the outcomes of the students' professional education;

- the reputation and competitiveness of the HEl;

- the educational-cultural environment of the $\mathrm{HEl}$;

- the prolific environment for the student-lecturer interaction, the key component of which is the lecturer's professional competency and the student support;

- ensuring reflective teaching/learning for the lecturers and students;

- pedagogical support to the students in the process of their adaptation to the culturaleducational environment of the $\mathrm{HEI}$ and to the teaching-upbringing process;

- creating an environment for academic freedom, as well as for the good academic conduct on the part of the lecturers and the students. 


\section{References}

Asatryan, L. (2014). Management of the modernization of education in the context of the contemporary pedagogical paradigm. Compilation of scientific-educational reports and articles. Yerevan: ASPU. 13-17.

Kuhn, Th. (2002). Structure of scientific revolutions, Moscow: AST Publishing House.

Popkov, V., Korzhuev, A. (2004). Theory and practice of higher professional education. Tutorial for high school: Moscow Academic Project.

General and professional pedagogy (2003). Manual for students of the specialty "Professional Education": In 2 books / Under the editorship of V. Simonenko, M. Retivykh. Bryansk: Publishing House of Bryansk State University. Book 1. [Electronic Resource]. URL: http: window.edu.ru/resource/448/56448/files/aist05.pdf. [Retrieved: 06/03/2019].

Bogo, M., Rawlings, M., Katz, E. and Logie, C. (2014) Using simulation in assessment and teaching. CSWE Press: Virginia.

Berman, R., McCartney, B.\&S. (2006). Competence is not enough: Meta-competence and accounting education// Received 01 Apr 1994, Accepted 01 Oct 1994, Pp. 4353 | Published online: 28 Jul 2006// https://www.tandfonline.com/doi/abs/10.1080/09639289500000006. [Retrieved: 31.05.2019].

Balakireva, E. (2008). Professional approach to the pedagogical education. Monograph. Saint Petersburg: Publishing House of RSPU After A. Herzen.

Ghukasyan, A., Asatryan, L., Karapetyan, A. (2005). Methods and tendencies in management at pedagogical university. Scientific-methodological manual. Yerevan.

Pollard, A., Collins, J. (2005). Reflective teaching. - A\&C Black.

Asatryan, M. (2013). Social pedagogical prerequisites for the implementation of studentcentered education at HEls. Compilation of materials dedicated to the $90^{\text {th }}$ anniversary of Kachatur Abovian ASPU. Yerevan: "Mankavarzh". 279-282.

\section{References (including translit)}

Asatrjan, L. (2014). Upravlenie modernizaciej obrazovanija $v$ kontekste sovremennyh pedagogicheskih paradigm. Modernizacija obrazovanija v kontekste sovremennyh pedagogicheskih paradigm. Sbornik nauchno-obrazovatel'nyh dokladov i statej. 
Erevan. AGPU. 13-17.

Kun, T. (2002). Struktura nauchnyh revoljucij. Izd-vo AST, M.

Popkov, V., Korzhuev, A. (2004). Teorija i praktika vysshego professional'nogo obrazovanija. Uchebnoe posobie dlja vysshhej shkoly: Moskva Akademicheskij Proekt.

Obshhaja i professional'naja pedagogika (2003). Uchebnoe posobie dlja studentov, obuchajushhihsja po special'nosti «Professional'noe obuchenie»: V 2-h knigah / pod red. V. Simonenko, M. Retivyh. Brjansk: Izd-vo Brjanskogo gosudarstvennogo universiteta, 2003. Kn. 1. [Jelektronnyj resurs]. URL: http:// window.edu.ru/resource/448/56448/files/aist05.pdf. [Data obrashhenija: 03.06.2019].

Bogo, M., Rawlings, M., Katz, E. and Logie, C. (2014) Using simulation in assessment and teaching. CSWE Press: Virginia.

Berman, R., McCartney , B.\&S. (2006). Competence Is Not Enough: Meta-Competence and Accounting Education// Received 01 Apr 1994, Accepted 01 Oct 1994, Pp. 43 53 | Published online: 28 Jul 2006// https://www.tandfonline.com/doi/abs/10.1080/09639289500000006. [Retrieved: 31.05.2019].

Balakireva, Je. (2008). Professiologicheskij podhod k pedagogicheskomu obrazovaniju. Monografija. - SPb. : Izd-vo RGPU im. A. Gercena.

Gukasjan, A., Asatrjan L., Karapetjan A. (2005). Metody i tendencii upravlenija v pedagogicheskom universitete. Nauchno-metodicheskoe posobie. Erevan.

Pollard, A., Collins, J. (2005). Reflective teaching. - A\&C Black.

Asatrjan, M. (2013). Social'no-pedagogicheskie predposylki dlja vnedrenija studentocentrirovannogo obrazovanija $v$ vuze, sbornik materialov, posvjashhennyh 90-letiju AGPU im. H. Abovjana. Er.: «Mankavarjh». Erevan. 279282. 